\title{
TRADITIONAL MEDICINES AMONGST INDIGENOUS GROUPS IN RORAIMA, BRAZIL: A RETROSPECTIVE
}

MEDICAMENTOS TRADICIONALES ENTRE GRUPOS INDÍGENAS EN RORAIMA, BRASIL: UNA RETROSPECTIVA

William Milliken $^{* 1}$

\begin{abstract}
:
Surveys of medicinal plants and fungi among five indigenous groups in Roraima, Brazil, were identified in 1993-95 in 11 communities by the author, but not published. Most of the 52 species reported here were unknown in the literature for the same medicinal purpose when the data were collected and have not been published due to intellectual property rights. However, 25 years later this has changed due to increased ethnobotanical surveys in Latin America. Some of the 'repeated' data were collected in Roraima, but most have been registered elsewhere in Amazonia. Most likely, some of the traditional ethnomedicine is already lost within the communities by now, with old informants not passing down their knowledge to younger generations. More work should be done on recording indigenous knowledge in Roraima about medicinal plants, preferably by indigenous people. Efforts to retrieve traditional knowledge through real participation from local communities will benefit culture, health, and means of subsistence amongst indigenous communities.
\end{abstract}

Keywords: Ethnobotany; Knowledge loss; Medicinal plants.

\section{Resumo:}

Pesquisas de plantas medicinais e fungos entre cinco grupos indígenas de Roraima, Brasil, foram identificadas em 1993-95 em 11 comunidades pelo autor, mas não publicado. A maioria das 52 espécies era desconhecida na literatura para o mesmo propósito medicinal quando os dados foram coletados, e não foram publicados devido a direitos de propriedade intelectual. No entanto, 25 anos depois, isso mudou devido ao aumento das pesquisas etnobotânicas na América Latina. Alguns dos dados "repetidos" foram coletados em Roraima, mas a maioria foi registrada em outro lugar na Amazônia. É provável que parte do conhecimento tradicional já tenha se perdido agora, com os informantes mais velhos não transmitindo seu conhecimento para as 
gerações mais jovens. Mais trabalho deve ser feito para registrar o conhecimento indígena em Roraima, preferencialmente pelos povos indígenas. Os esforços para recuperar o conhecimento tradicional, através da participação real com as comunidades locais, irá beneficiar a cultura, saúde e meios de subsistência entre as comunidades indígenas.

Palavras-chave: Etnobotânica; Perda de conhecimento; Plantas.

\section{Introduction}

Knowledge about medicinal plants by indigenous people in the Amazon remains important for healthcare, particularly within isolated communities. A survey of medicinal plants and pharmaceuticals in the Bolivian Amazon and the Andes showed that indigenous informants who are more distant from primary health care services or villages use more medicinal plants and have a greater knowledge about these plants (VANDEBROEK et al., 2004). A study of the use of phytotherapies and biomedicine to treat fevers and malaria in French Guiana demonstrated that indigenous people use more medicinal plants to treat malaria than the other informants (Creoles, French, and Brazilians) (ODONNE et al., 2021). Destruction of habitats and loss of knowledge of medicinal plants are significant and growing threats (CÁMARA-LERET et al., 2019; SHANLEY AND LUZ, 2003). The loss of medicinal plant knowledge is a global problem, partly linked to the loss of indigenous languages (CÁMARA-LERET AND BASCOMPTE, 2021). Over 15 years, in Kenya, 40\% on the medicinal species were no longer used, largely due to a change from nomadic to a more sedentary lifestyle (BUSSMANN et al., 2018).

Transmission and modification of knowledge between generations and communities are complex, and planning interventions to mitigate it requires better understanding of the dynamic processes (ZENT, 2013). Integrating ethnobotany and ethnopharmacology can contribute to a more integrated framework for healthcare in underserved and minority communities, but this research should be designed for greater intrinsic value to the communities, health priorities, and perceptions, in a true partnership with local communities (VANDEBROEK, 2013).

Data were collected as part of a wider survey of medicinal plants used to treat malaria in Roraima, Brazil. As an example, up to $20 \%$ of the Yanomami people in Brazil were killed by malaria and other diseases between 1987 and 1990 (PELLEGRINI, 1996). Although most of the plant species have now been published for the same medicinal use, in many cases they are not used by the same people. Cross-verification of medicinal plants is now commonly used, and cited in academic papers, as a measure of the importance within the community. An alternative to this methodology is to measure the importance between countries/regions or separate peoples, possibly independently, to assess the likelihood of the species containing active medicinal compounds (BLETTER, 2007; HAWKINS AND TEIXIDOR TONEU, 2017; MILLIKEN et al., 2021; SASLIS-LAGOUDAKIS et al., 2011).

This paper discusses the data collected in Roraima, within the context of current published information in other regions in South America, as a means of crossverification. It also discusses the importance and issues of maintaining traditional knowledge amongst indigenous peoples, and how ethnobotanists could play a better part in protecting and facilitating knowledge transfer to future generations through joint action and collaboration. 


\section{Material and Methods}

The data published in this paper were collected with the Ingarikó, Macuxi (Makuxi), Taurepang, Wai-Wai, and Wapishana (Wapixana) people, between 1993 and 1995. This was part of a larger study that included all the indigenous peoples in Roraima, including the Ye'kwana and the Yanomami. The data were collected in Jatapuzinho (Wai-Wai), Manalai and Serra de Sol (Ingarikó), Bananal (Taurepang), Boca da Mata, Raposa, Maturuca and Sorocaima II (Macuxi), Araca, Malacacheta (Wapishana), and Mangueira (Figure 1).

The informants within the communities were identified through initial focus groups including knowledge holders. The project was explained to the community, during which community leaders gave permission to collect data. Further identified informants were recruited through the 'snowball' (non-probabilistic) technique (BERNARD, 2006). Medicinal plants, presented by male and female informants, were then recorded in individual discussions in the village, and then during 'guided' tours in the field (in Portuguese). For the individual interviews, there was only one question in the survey: "Do you use any plants to treat or cure malaria?". No other question was posed about other plant-based medicines. The only group discussion took place at a health meeting organized by the International Organization Médecins Sans Frontières, in Mangueira.

Voucher specimens were collected and are housed in the herbaria at Kew (K), Museu Integrado de Roraima (MIRR), Instituto Nacional de Pesquisas da Amazônia (INPA) and the New York Botanical Garden (NY). Some of the sterile specimens were not stored in the official herbarium collections, but a full set of specimens is maintained at Kew. In a very few cases, no specimen was collected when the plants were easily identified (Appendix 1). When the data were collected in the 1990s, the author was concerned about publishing information about certain species (due to intellectual property), unless the same species/use had been already published elsewhere. Data on antimalarial use had been published by MILLIKEN (1997) but other medicinal plants data had not. The data in this paper were collected by the same informants from the antimalarial project, in some cases for other medicinal uses of antimalarial plants, or from other (nonantimalarial) species collected during 'guided' tours in the field.

When the data were collected in the field, the authorization was given directly from CNPq, via the Universidade de Brasília (UNB). The responsible Brazilian researcher was Professora Alcida Rita Ramos. Permission to visit the communities was granted by FUNAI, rather than directly from the indigenous communities, but with assistance from the Conselho Indígena de Roraima (CIR) and the Associação dos Povos Indígenas de Roraima (APIR).

The plants were collected in the northern savanna (lavrado) and the tropical forest. The lavrado in Roraima is similar to the cerrado in Central Brazil, with a mosaic appearance, but with ecological and floristic differences, with fewer plant species (BARBOSA AND MIRANDA, 2005). In 2014, the Brazilian population of the tribes was 33,603 Macuxi, 9,441 Wapishana, 2502 Wai-Wai, 1488 Ingarikó, and 792 Taurepang (INSTITUTO SOCIOAMBIENTAL, 2018). All these people speak the Karib language, apart from the Wapishana, who speak Aruak. Apart from Roraima, most tribes are also present in 
Guiana and Venezuela, but the Wai-Wai are also living in Pará and Amazonas, two Northern states in Brazil.

The indigenous names of the plants (Appendix 1) were written using two vowels in nonIPA symbols: i refers to a close/tense, high central unrounded vowel, and ë refers to a mid-central vowel (like schwa/q/vowel similar to the English word cut). These were based on previous work with the Yanomami (MILLIKEN AND ALBERT, 1996), and doubtlessly some of these names are slightly misspelled.

The species have been updated, to reflect Plants of the World Online taxonomy www.plantsoftheworldonline.org. In Appendix 1 the 'contemporary' uses of the same species for the same or similar purposes are shown. All the informants and their locations/indigenous peoples are cited in Appendix 1.

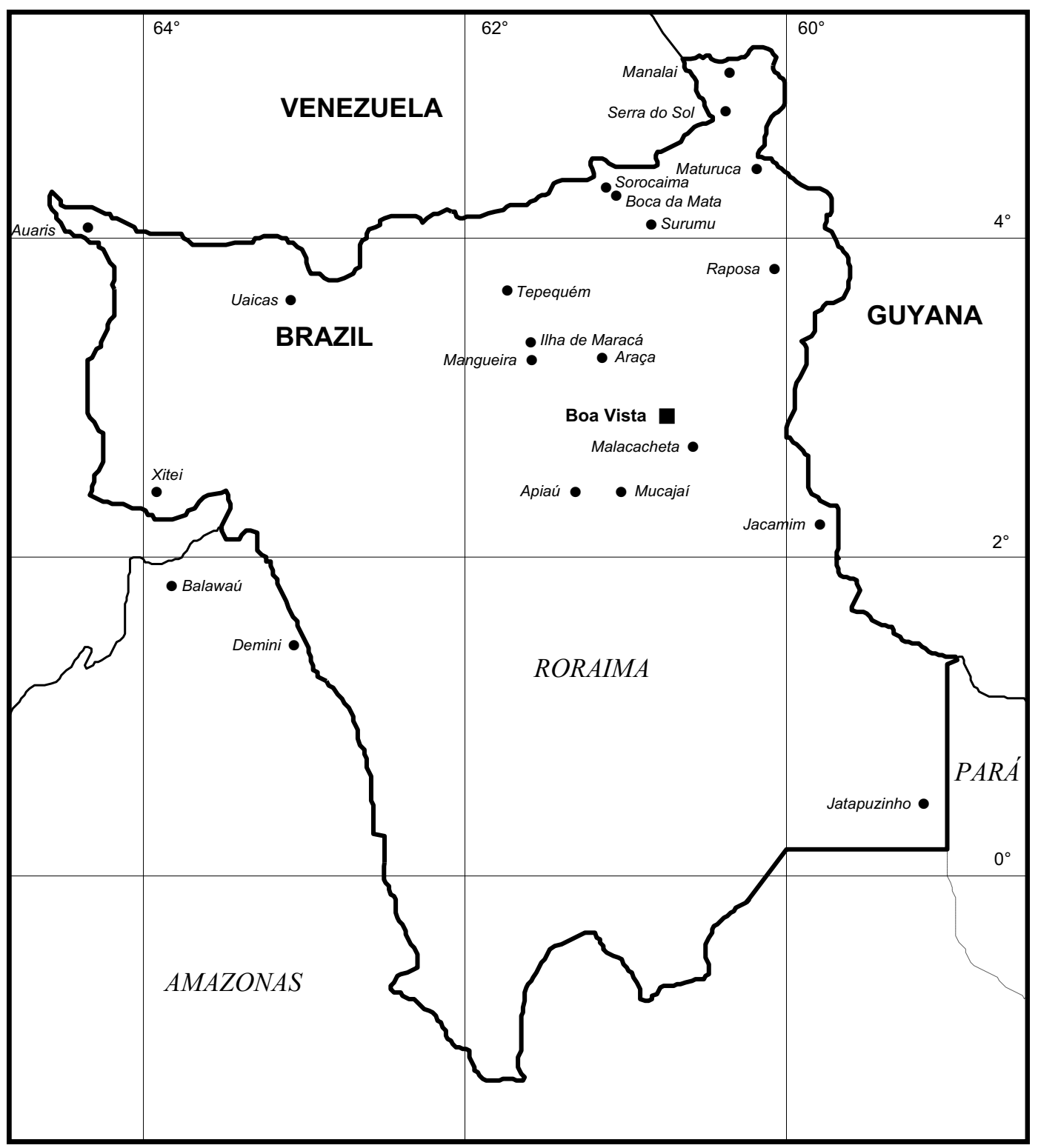

Figure 1: Approximate locations of the sites studied in 1993-5. Source: Milliken (1997). 


\section{Results}

Fifty-one medicinal plant species and one fungus are cited here (Appendix 1), of which 7 were cultivated. This includes 17 species used to treat diarrhoea/stomachache/dysentery, 7 to treat skin diseases and thrush, 6 to treat wounds and sores, 6 to treat coughs/colds, and 4 to treat kidney/urinary problems. Most of the medicines are taken internally as infusions or decoctions (apart from one, as a bath for fevers), and as treatment for wounds, toothache, eye disorders, skin sores etc. This study, however, was not quantitative. Advances in ethnobotanical procedures have attempted to analyse the data in various forms (e.g. importance), but the prime interest in the original project was simply recording species used to treat malaria, collect samples for analysis (anti-plasmodial properties and toxicity), and then share the data with indigenous peoples, including through the Conselho Indigenista Missionário CIMI (MILLIKEN, 1995a). The main purpose was an attempt to mitigate the malaria outbreak caused by illegal gold miners (garimpeiros) in the 1990s, which now have another resurgence; the number of malaria cases in the state almost tripled between 2016 and 2018 (LOUZADA et al., 2020). As the survey was not quantitative, it is not possible to compare accurately how many medicinal plants are used within the communities, or between indigenous groups, and likewise summarize accurately how the plants are used more broadly. However, this is further explained in the Discussion.

\section{Discussion}

\subsection{Knowledge of medicinal plants}

Of the plants cited here, 11 (21\%) of the species were previously published as antimalarials (with the same informants) in MILLIKEN (1997). However, the information on non-malarial medicinal use was not cited in the former paper. The other species and their medicinal uses were found during 'guided' tours. However, as the focus was on antimalarial plants, the informant did not present all their knowledge of medicinal species. We cannot, therefore, determine which people know more about medicinal plants than others.

If one is looking for an antimalarial plant and, in the process, sees another medicinal species on the way, it could be used to treat anything. My experience with older informants in Amazonia is that once you start asking about plant use, they are keen to tell you about any plant properties, even if you are focused on a smaller sub-sample (malaria). For example, in the unpublished information on 113 species that I collected (in the same period) with the Ye'kwana indigenous people in Roraima, 30 were antimalarials and 83 had other medicinal uses. Of the 30 antimalarial species, 10 were also used to treat gastrointestinal problems.

\subsection{Correlation with published surveys}

In terms of the species cited in this paper, most are now known to be used for the same purposes elsewhere in Latin America. This is partly due to an increase in ethnobotanical surveys/publications in the Amazon over the last 25 years, including in Brazil (RITTER et al., 2015), although the focus has been in the Northeast and Southwest, and in the Atlantic forest and caatinga. In Roraima, however, relatively few advances have been done since our data were collected. There were ethnobotanical surveys in 
Boa Vista, the capital city (DA COSTA PINTO AND MADURO, 2003; LUZ, 2001), a review of medicinal plants and health in Boa Vista peripheral districts (77 spp.) (ARAÚJO, 2018), a study of three species used by the Macuxi (DE OLIVEIRA et al., 2017a-b), an ethnobotanical survey (91 spp.) of the Macuxi and Wapishana in São Marcos (DE OLIVEIRA, 2016), and a survey of 119 medicinal species among the non-indigenous riverine communities on the border of Roraima and Amazonas (Jauaperi River) (PEDROLLO et al., 2016).

Earlier studies (prior to this survey) included an unpublished list (51 spp.) of Macuxi medicinal plants (DOYLE, 1985) and a list of plants collected along the BR174 highway (VAN DEN BERG AND SILVA, 1988). However, no thorough survey of medicinal plants has been conducted with indigenous peoples in Roraima State.

Of the 52 species cited in this paper, there were 66 species/medicinal use combinations. Of these, 50 corresponding species/use combinations have been recorded in the literature. Of the 16 that are not published in the literature, 11 have the same use for other species in the genera. Among the species that appear not to be used for the same purpose, some have multiple medicinal uses for other purposes. Bauhinia ungulata L., for example, which is used by the Macuxi to treat tuberculosis, is widely used as a medicine in Latin America for diabetes, diarrhoea, pain, malaria, and wounds (BIESKI et al., 2012; DE OLIVEIRA, 2016; MILLIKEN, 1997; RIBEIRO et al., 2017). Bauhinia vahlii Wight \& Arn. is used to treat tuberculosis in India and has antimicrobial activity (NGUYEN et al., 2021).

In very few cases there are no known references to the species as a medicinal plant. For example, Ayenia tomentosa L., used by the Macuxi to treat grippe (influenza) is not cited in the literature as a medicine, although Ayenia magna L. is used to treat diarrhoea in Yucatán, Mexico (VERA-KU et al., 2010). Likewise, Leptolobium stirtonii (Aymard \& V.González) Sch.Rodr. \& A.M.G.Azevedo has no medicinal references, but L. nitens Vogel has the same medicinal uses (headache and tooth decay) in Roraima (DE OLIVEIRA, 2016). Macrolobium bifolium (Aubl.) Pers., used to treat diarrhoea by the Ingarikó, is not cited in the literature but minor antimicrobial activity against Staphylococcus aureus has been demonstrated (ROVIRA et al., 1999). Heisteria scandens Ducke, to treat burns by the Wai-Wai, is not known as a medicinal plant, but H. acuminata (Bonpl.) Engl. is used to treat wounds 'that will not heal' in Peru (AYALA, 1996).

Some species are widely used for the same purpose in Latin America, such as Hymenaea courbaril L. for treating coughs, Dianthera pectoralis (Jacq.) J.F. Gmel for pain, Philodendron spp. for ant stings and snakebite, Byrsonima crassifolia (L.) Kunth for diarrhoea, and Phyllanthus spp. for kidney infections. In a few cases, the same plants and their uses have been recorded previously in Roraima, such as Himatanthus articulatus (Vahl) Woodson and Palicourea rigida Kunth (kidney stones), Carica papaya L. (vomiting), and Byrsonima verbascifolia (L.) DC. (diarrhoea). Others were used in Roraima, but for other purposes, such as Carapa guianensis Aubl. for healing and influenza (ARAÚJO, 2018). The most important species used by the Macuxi and Wapishana, based on use value estimates, were Himatanthus articulatus and Leptolobium nitens (possibly L. stirtonil) (DE OLIVEIRA, 2016), and the most traded species in Boa Vista markets included Hymenaea courbaril, Copaifera sp. and $H$. articulatus (DA COSTA PINTO AND MADURO, 2003), all of which are cited in this paper.

Several species/use combinations are not known in Roraima but are recorded in other districts or countries. Sagotia racemosa Baill. is used to treat toothache among the Wai- 
Wai, and earache by the Jivaro in Peru, which are often connected with toothache (KIM et al., 2007). In a few cases, the informant described the illness, but it was difficult to classify it. Senna obtusifolia (L.) Irwin \& Barneby, for example, is used by the Wapishana to cure 'skin disorders (red rash)'. Perhaps, it is a reference to measles, for which it is used under the same purpose in Peru (SANZ-BISET AND CANIGUERAL, 2011). Likewise, Ampelozizyphus amazonicus Ducke, which is used by the Wai-Wai for severe 'cough with blood', may refer to tuberculosis. This species is also used for treating tuberculosis elsewhere in the Amazon (STOREY AND SALEM, 1997).

The sample was relatively small, so it is not possible to evaluate 'shared' data between Carib-speaking indigenous people. However, in some cases, the only correlating species/use combinations within the literature were between the Ingarikó in Brazil and the Patamona in Guiana, e.g. the latex of Aspidosperma excelsum Benth. to treat eye infections and the grated nut of Carapa guianensis Aubl. to treat measles and chickenpox (DEFILIPPS et al., 2004). The Ingarikó, Patamona, and Akawaio people share their same common name (kapon) 'celestial people' surrounding Mount Roraima and are very closely related.

\subsection{Loss of knowledge and research perspectives}

Some of the data presented in this paper, provided by the older informants 25 years ago, may now have been lost. The medicinal plant data that were collected amongst the Ye'kwana indigenous people in Roraima in the 1990s are not published in this paper. In 2018 the author contacted Seduume (the Ye'kwana Association) and ISA (Instituto Socioambiental) regarding the possibility of collaborating to research Ye'kwana medicinal plants more broadly. Seduume agreed as they said that the information was not being passed down from older 'sábios' (knowledge holders) to younger generations and that their knowledge would soon be lost forever. Therefore, we set up a new (current) project, conducted by the Ye'kwana indigenous researchers, to catalogue their knowledge and produce an illustrated book in their own language for future generations.

Similarly, in terms of the medicinal plant knowledge of the Yanomami in Brazil (Amazonas and Roraima), we published data in the 1990s with similar uses in the literature (MILLIKEN AND ALBERT, 1996; 1997). Those that were not published elsewhere for the same purpose were excluded from these papers. Twenty years later we returned to the Yanomami and trained indigenous researchers to document their knowledge and publish a book in their own language and Portuguese (YANOMAMI et al., 2015). It was evident that knowledge holders had not passed down their knowledge of medicinal plants to younger generations since it was first recorded.

As Justino, one of the Yanomami knowledge holders, said: "Here, people refuse the forest remedies because they don't know them, they don't use them for treatment, they prefer white people's medicine, even if I indicate for them how to do it. When the Kamakari 'being' eats inside the ear, I say you must roll cotton with bark from a tree and put it in the ear, but they don't pay attention to me; the old ones used cotton with the nahara hi bark (Zanthoxylum pentandrum (Aubl.) R.Howard) for this. I say these things, but they don't pay attention to me, because they don't know. Because they like white things better... In the past, people were very smart because they spent time away on expeditions gathering and camping in the forest. People now no longer travel in the forest, that's why they don't know the medicines, they are always in the house, and 
that's why they don't know! People spent a lot of time camping for collecting and went far on expeditions to hunt! Therefore, they really knew the remedies, they lived a long time in the forest; it was like this. Now, after we get close to the whites, we don't travel anymore, and young people no longer know these remedies. People no longer ask themselves: "Are we going to travel?". That's why they don't know!" (YANOMAMI et al., 2015).

The loss of traditional knowledge will be the case for many other indigenous peoples in the Amazon, partly due to development, displacement, deforestation, and society degradation (CABALLERO-SERRANO et al., 2019; REYES-GARCÍA et al., 2013; WECKMÜLLER et al., 2019). Research of traditional medicines among indigenous peoples, together with wider perspectives on ethnobotany and traditional knowledge, requires further work in the Amazon (CÁMARA-LERET et al., 2014). In terms of publications, however, there have been significant changes. Many indigenous peoples in the Amazon now have established 'associations', such as Hutukara (Yanomami) and Seduume (Ye'kwana), who can decide how their knowledge should be recorded (and conveyed).

While training the Ye'kwana researchers to collect medicinal plant knowledge, I taught them to collect and prepare specimens for identification. At the end of the training, we had a meeting with the knowledge holders to discuss the final process and the outputs. The oldest 'sábio', with whom I had worked with in the 1990s (collecting his extraordinary knowledge and taking voucher specimens), decided that taking specimens away from the community might reduce the 'power' of the plants. He asked whether the original 1990s specimens, which are stored in the herbaria at K, MIRR, INPA, and NY, could be returned to the community. As a result of the discussion, the project was adapted, and identification of the medicinal plants is only done through photography.

To assess the loss of medicinal knowledge within indigenous communities is extremely hard to do without complete longitudinal surveys (with a gap of several years between each measurement). A broader analysis regarding the loss of ecological knowledge suggests that the highest loss is in medicinal and ethnobotanical knowledge, particularly amongst men (ASWANI et al., 2018). However, the lack of longitudinal data remains a problem for estimating the impact over time. One study, among the Tsimane' adults in the Bolivian Amazon between 2000 and 2009, suggests that there was a net decrease of plant use from 9\% (for women) to $26 \%$ (for people living close to cities) (REYES-GARCÍA et al., 2013). Comparing the Macuxi and Wapishana data presented here with more recent surveys of the medicinal plants among those people, $38 \%$ of the species/use combinations were not previously recorded in the literature. But this does not mean that the data were necessarily lost, as the surveys are far from complete.

Collecting traditional knowledge now requires a signed Informed Consent Form, helping the informant decide how the information could be used, and for what purpose, before giving agreement. In Brazil, there are new laws relating to the transmission of indigenous knowledge (SILVA AND OLIVEIRA, 2018). The aim of these laws is to help ensure that possible financial benefits from that knowledge can be shared with the original owners. However, a study and analysis in Northeast Brazil suggested that residents did not understand the Informed Consent Form, and that the residents should be willing to participate in any return and extension activities, which requires planning from design phase to final completion (DE ALBUQUERQUE et al., 2012). 
Traditional knowledge of indigenous communities in Roraima requires more investment and research. The Wai-Wai, both within Roraima, Pará, and Guiana, have not been properly studied, and likewise the Taurepang and the Ingarikó. New projects, preferably led by indigenous researchers, should catalogue this knowledge before it disappears. In 1995 the author wrote that the malaria project needs careful consideration of the intellectual property rights of the people involved and illustrates a role for the ethnobotanist that has too rarely been realised up to this moment. Not as a medium to transfer potentially valuable information from indigenous peoples to the developed world, but as a medium for mutually beneficial transfer of information between indigenous peoples (MILLIKEN, 1995b). Has this happened since then?

There have been several efforts, such as the Acaté project in Peru, to document the knowledge of the Matsé healers and pass down the knowledge to younger generations. In the quilombola communities in the Atlantic forest in Brazil (RODRIGUES et al., 2020), the Chacobo in Bolivia (PANIAGUA-ZAMBRANA et al., 2018), and the Maya in Guatemala (HITZIGER et al., 2016), local researchers were trained, and the development of the project was planned in collaboration with local communities. Engaging young researchers in the process is crucial, but this is not always easy. A study of Trio indigenous ethnomedicine demonstrated that simply collecting the data would not maintain indigenous self-sufficiency, but would require active practice (HERNDON et al., 2009).

From our experience with the Yanomami (YANOMAMI et al., 2015), young indigenous researchers were keen to participate, but when the project is finished and they develop new skills, there is no incentive to carry on with research. The long-term impact on the projects, in terms of maintaining the traditional knowledge for future generations, and its impact on healthcare, has not been properly researched. Nevertheless, in a study of the Chácobo in Brazil, the engagement of trained local interviewers elicited a large percentage of novel information (PANIAGUA-ZAMBRANA et al., 2018)

It is recommended that informants should be co-authors in ethnobotany papers if they have played significant roles in the projects (RAMIREZ, 2007). The Nagoya Protocol for non-monetary benefits requires joint ownership of relevant intellectual property rights (CONVENTION ON BIOLOGICAL DIVERSITY, 2011). This paper, unfortunately, does not include indigenous authors here as the data were collected 25 years ago. Some of the informants have probably already passed away, and communicating with those still alive would be very hard (or even impossible). Most ethnobotanical surveys over the last five years still do not include informants as co-authors, although there are a few exceptions such as YANOMAMI et al. (2015); KFFURI et al. (2016); RAMÍREZ AND BLAIR (2017); ZAMBRANA et al. (2017).

Twenty-five years since the author first wrote an academic paper on medicinal plants in Brazil, there is still no online dataset of medicinal species and their uses. Comparing data cited in the paper with other uses (cross-verification) requires re-reading books and articles, and (now) scanning the internet for online publications. This is a substantial amount of effort, repeated by many other ethnobotanical contributors. In order to understand how data are transferred between people, how multiple references from different regions suggest investment in medical research, and how to promote and adapt ethnomedicine in healthcare will require better, organised, and accessible data (DE SOUZA AND HAWKINS, 2020). More importantly, returning data so they can be shared appropriately and comprehensibly amongst the people who need them requires greater research, technology, communication, and financing. 


\section{Conclusions}

The data presented here on medicinal plant use amongst five indigenous peoples in Roraima have strong correlations with the use of these species by other peoples and indigenous communities within the Amazon. However, the research on medicinal plant use amongst these indigenous peoples is very far from complete. Traditional knowledge of indigenous communities, both within Roraima and more broadly in South America, needs to be recorded rapidly before it is lost forever due to acculturative, ecological, and behavioural changes and cultural transmission. For research to make a greater impact on the transmission of knowledge to younger generations will require new, developing ethnobotanical approaches. These include: greater engagement and collaboration of local communities through joint action and practice; training indigenous/community researchers in long-term projects; ensuring that the data are made available to the communities in an appropriate form; recognising the contribution of the knowledge holders; and a greater focus on health priorities, perceptions and impact to the communities. Improved, accessible datasets of all medicinal plants throughout South America would assist the research/analysis, the transfer of knowledge between and within the communities, and the potential development of novel medicines.

\section{Acknowledgements}

The original project at Kew was funded by Baring Foundation, the Ernest Cook Trust, and the Rufford Foundation. It was conducted in collaboration and with assistance from the Universidade de Brasília (UNB), the Museu Integrado de Roraima (MIRR) and the Instituto Nacional de Pesquisas da Amazônia (INPA Roraima). Further support was given by Conselho Indigena de Roraima (CIR), Associação dos Povos Indígenas de Roraima (APIR), Fundação Nacional de Saúde (FNS), Fundação Nacional de Indio (FUNAI) and the Instituto Brasileiro do Meio Ambiente (IBAMA). Alcida Ramos, Celso Morato de Carvalho, Ana Paulo Souto Minor, Reinaldo Imbrozio Barbosa and Ari Weiduschat contributed to research and/or facilitation.

The data on medicinal plants were kindly provided by Totoari (Wai-Wai), Narcisa, Arlindo, Martins, Clarenço, João Sales (Ingarikó), Raimundo, Joachim, João, Ines, Ignacio, Virginia, Ivaldo, Dulcimar, Martins, Maria Lucia, Teresa (Macuxi), Bento (Taurepang), Oreco, Alvino and Araca (Wapishana).

\section{References -}

ACOSTUPA, R. J. H.; BARDALES, J. J. A.; TECO, R. M. V. Uso de las plantas medicinales en la comunidad El Chino, del área de conservación regional comunal TamshiyacuTahuayo, Loreto, Perú. Conocimiento Amazónico, Iquitos, v. 4, n. 2, p. 77-86. 2016.

AGRA, M. D. F. et al. Survey of medicinal plants used in the region Northeast of Brazil. Revista Brasileira de Farmacognosia, v. 18, n. 3, p. 472-508. 2008. https://doi.org/10.1590/s0102-695x2008000300023. Accessed on: Jul. 29, 2021. 
ALVES, E. O. et al. Levantamento etnobotânico e caracterização de plantas medicinais em fragmentos florestais de Dourados-MS. Ciência e Agrotecnologia, Lavras, v. 32, n. 2, p. 651-658. 2008. https://doi.org/10.1590/s1413-70542008000200048. Accessed on: Jul. 29, 2021.

ANTUNES MACIEL, M. R.; GUARIM NETO, G. Um olhar sobre as benzedeiras de Juruena (Mato Grosso, Brasil) e as plantas usadas para benzer e curar. Boletim do Museu Paraense Emílio Goeldi. Ciências Humanas, Belém, v. 1, n. 3, p. 61-77. 2006. https://doi.org/10.1590/s1981-81222006000300003. Accessed on: Jul. 29, 2021.

ARAMBARRI, A. M. et al. Leaf anatomy of medicinal shrubs and trees from Misiones forest of the Paranaense Province (Argentina). Part 2. Boletín Sociedad Argentina de Botánica, Corrientes, v. 43, n. 1-2, p. 31-60. 2008.

ARAÚJO, K. A. Knowledge of medicinal plants used by residents in two peripheral districts of Boa Vista, Roraima, Northern Brazilian Amazon: Phytotherapy as a new strategy in collective health. Journal of Medicinal Plants Research, v. 12, n. 26, p. 435447. 2018. https://doi.org/10.5897/jmpr2018.6634. Accessed on: Jul. 29, 2021.

ASWANI, S.; LEMAHIEU, A.; SAUER, W. H. Global trends of local ecological knowledge and future implications. PLoS One, San Francisco, v. 13, n. 4, p. e0195440. 2018. https://doi.org/10.1371/journal.pone.0195440. Accessed on: Jul. 29, 2021.

AYALA, E. M. L. J. The ethnobotany of the Mestizo people of Suni Miraño, Peru. 1996. 89 f. (B.Sc). University of British Columbia, Pomona, 1996.

BARBOSA, R. I.; MIRANDA, I. D. S. Fitofisionomias e diversidade vegetal das savanas de Roraima. In: R.I. Barbosa; H. A. M. Xaud; J. M. Costa e Souza (eds.) Savanas de Roraima: etnoecologia, biodiversidade e potencialidades agrossilvipastoris. Boa Vista, Femact, p. 61-78. 2005.

BARRETT, B. Medicinal plants of Nicaragua's Atlantic coast. Economic Botany, New York, v. 48, n. 1, p. 8-20. 1994. https://doi.org/10.1007/bf02901375. Accessed on: Jul. 29, 2021.

BENNETT, B.; ALARCÓN, R. Osteophloeum platyspermum and Virola duckei (Myristicaceae): newly reported as hallucinogens from Amazonian Ecuador. Economic Botany, New York, v. 48, n. 2, p. 152-158. 1994. https://doi.org/10.1007/bf02908205. Accessed on: Jul. 29, 2021.

BERNARD, H. Research Methods in Anthropology: Qualitative and Quantitative Approaches. Oxford: AltaMira Press. 2006.

BIESKI, I. G. C. et al. Ethnobotanical study of medicinal plants by population of valley of Juruena region, legal Amazon, Mato Grosso, Brazil. Journal of Ethnopharmacology, Pretoria, v. 173, p. 383-423. 2015. https://doi.org/10.1016/j.jep.2015.07.025. Accessed on: Jul. 29, 2021.

BIESKI, I. G. C. et al. Ethnopharmacology of medicinal plants of the pantanal region (Mato Grosso, Brazil). Evidence-Based Complementary and Alternative Medicine, v. 2012, p. 1-36. 2012. https://doi.org/10.1155/2012/272749. Accessed on: Jul. 29, 2021.

BITENCOURT, B. L. G.; LIMA, P. G. C.; BARROS, F. B. Comércio e uso de plantas e animais de importância mágico-religiosa e medicinal no mercado público do Guamá, Belém do Pará. Revista FSA (Centro Universitário Santo Agostinho), Agostinho, v. 11, n. 3, p. 96-158. 2014. https://doi.org/10.12819/2014.11.3.5. Accessed on: Jul. 29, 2021. 
BLETTER, N. A quantitative synthesis of the medicinal ethnobotany of the Malinke of Mali and the Asháninka of Peru, with a new theoretical framework. Journal of Ethnobiology and Ethnomedicine, Nashville, v. 3, n. 1, p. 36. 2007. https://doi.org/10.1186/1746-4269-3-36. Accessed on: Jul. 29, 2021.

BUSSMANN, R. W. et al. Knowledge loss and change between 2002 and 2017-a revisit of plant use of the Maasai of Sekenani Valley, Maasai Mara, Kenya. Economic Botany, New York, v. 72, n. 2, p. 207-216. 2018. https://doi.org/10.1007/s12231-018-9411-9. Accessed on: Jul. 29, 2021.

CABALLERO-SERRANO, V. et al. Traditional ecological knowledge and medicinal plant diversity in Ecuadorian Amazon home gardens. Global Ecology and Conservation, v. 17, p. e00524. 2019. https://doi.org/10.1016/j.gecco.2019.e00524. Accessed on: Jul. 29, 2021.

CÁCERES, A. Plantas de uso medicinal en Guatemala. Editorial Universitaria. Universidad de San Carlos de Guatemala. 1996

CÁMARA-LERET, R.; BASCOMPTE, J. Language extinction triggers the loss of unique medicinal knowledge. Proceedings of the National Academy of Sciences, Washington, v. 118, n. 24, p. e2103683118. 2021. https://doi.org/10.1101/2020.12.03.407593. Accessed on: Jul. 29, 2021.

CÁMARA-LERET, R.; FORTUNA, M. A.; BASCOMPTE, J. Indigenous knowledge networks in the face of global change. Proceedings of the National Academy of Sciences, Washington, v. 116, n. 20, p. 9913-9918. 2019. https://doi.org/10.1073/pnas.1821843116. Accessed on: Jul. 29, 2021.

CÁMARA-LERET, R. et al. Ethnobotanical knowledge is vastly under-documented in northwestern South America. PloS one, San Francisco, v. 9, n. 1, p. e85794. 2014. https://doi.org/10.1371/journal.pone.0085794. Accessed on: Jul. 29, 2021.

CAVALCANTE, P. B.; FRIKEL, P. A famacopéia Tiriyó: estudo étno-botânico. Publicações Avulsas do Museu Paraense Emílio Goeldi, Belém, v. 24, p. 1-145, 1973.

CONVENTION ON BIOLOGICAL DIVERSITY. Nagoya Protocol on Access to Genetic Resources and the Fair and Equitable Sharing of Benefits arising from their Utilization to the Convention on Biological Diversity. Montreal: Secretariat of the Convention on Biological Diversity. 2011.

DA COSTA PINTO, A. A.; MADURO, C. B. Produtos e subprodutos da medicina popular comercializados na cidade de Boa Vista, Roraima. Acta Amazônica, Manaus, v. 33, n. 2, p. 281-290. 2003. https://doi.org/10.1590/1809-4392200332290. Accessed on: Jul. 29, 2021.

DA MATA, N. D. S. et al. The participation of Wajãpi women from the State of Amapá (Brazil) in the traditional use of medicinal plants - a case study. Journal of Ethnobiology and Ethnomedicine, Nashville, v. 8, n. 1, p. 48.2012. https://doi.org/10.1186/1746-4269-8-48. Accessed on: Jul. 29, 2021.

DAVIS, E. W.; YOST, J. A. The ethnomedicine of the Waorani of Amazonian Ecuador. Journal of Ethnopharmacology, Pretoria, v. 9, n. 2-3, p. 273-297. 1983. https://doi.org/10.1016/0378-8741(83)90036-3. Accessed on: Jul, 29, 2021.

DE ALBUQUERQUE, U. P. et al. Medicinal plants of the caatinga (semi-arid) vegetation of NE Brazil: a quantitative approach. Journal of Ethnopharmacology, Pretoria, v. 114, n. 3, p. 325-354. 2007. https://doi.org/10.1016/j.jep.2007.08.017. Accessed on: Jul. 29, 2021. 
DE ALBUQUERQUE, U. P. et al. "Return" and extension actions after ethnobotanical research: the perceptions and expectations of a rural community in semi-arid Northeastern Brazil. Journal of Agricultural and Environmental Ethics, v. 25, n. 1, p. 1932. 2012. https://doi.org/10.1007/s10806-010-9296-9. Accessed on: Jul. 29, 2021.

DE OLIVEIRA, A. T. S. et al. Diabetes, câncer e hipertensão: tratamento auxiliar com plantas medicinais usadas por populares em Mato Grosso. In: SEMANA DA ENFERMAGEM DA AJES, 2015, Guarantã do Norte. 2015.

DE OLIVEIRA, R. L. C. et al. Uso e conhecimento da copaíba (Copaifera Pubiflora benth.) pela comunidade Makuxi Darora na savana de Roraima. In: XII Semana Nacional de Ciência e Tecnologia em Roraima, 2017-a, Boa Vista. Anais de Congresso p. 421-425.

DE OLIVEIRA, R. L. C.; SCUDELLER, V. V.; BARBOSA, R. I. Use and traditional knowledge of Byrsonima crassifolia and B. coccolobifolia (Malpighiaceae) in a Makuxi community of the Roraima savanna, northern Brazil. Acta Amazonica, Manaus, v. 47, n. 2, p. 133-140. 2017-b. https://doi.org/10.1590/1809-4392201600796. Accessed on: Jul. 29, 2021.

DE OLIVEIRA, S. K. D. Etnobotânica em duas comunidades da Terra Indígena São Marcos, Roraima, Brasil. 2016. 113 f. (PhD). Instituto de Ciências Biológicas, Universidade Federal do Pará, Belém, 2016.

DE SOUZA, E. D. N. F.; HAWKINS, J. A. Ewé: a web-based ethnobotanical database for storing and analysing data. Database, v. 2020, n. 2020, p. 1-9. 2020. https://dx.doi.org/10.1093\%2Fdatabase\%2Fbaz144. Accessed on: Jul. 29, 2021.

DE SOUZA, M. D.; PASA, M. C. Levantamento etnobotânico de plantas medicinais em uma área rural na região de Rondonópolis, Mato Grosso. Biodiversidade, v. 12, n. 1, p. 138145. 2013.

DEFILIPPS, R. A.; MAINA, S. L.; CREPIN, J. Medicinal plants of the Guianas (Guyana, Surinam, French Guiana). Washington: Department of Botany, National Museum of Natural History, Smithsonian Institution. 2004.

DI STASI, L. et al. Medicinal plants popularly used in Brazilian Amazon. Fitoterapia, v. 65, n. 6, p. 529-540. 1994. https://doi.org/10.1016/S0367-326X(01)00362-8. Accessed on: Jul. $29,2021$.

DOS SANTOS, F. J. et al. Composition and biological activity of essential oils from Lippia origanoides HBK. Journal of Essential Oil Research, v. 16, n. 5, p. 504-506. 2004. https://doi.org/10.1080/10412905.2004.9698782. Accessed on: Jul. 29, 2021.

DOYLE, M. Contribuição à flora medicinal dos índios Macuxi, 1985.

DUKE, J.; VASQUEZ, R. Amazonian ethnobotanical Dictionary. Florida: Boca Raton. 1994.

FERREIRA, F. M. et al. Levantamento de plantas medicinais e do conhecimento etnobotânico no município de Baependi, Minas Gerais, Brasil. MG.BIOTA, Belo Horizonte, v. 5, n. 6, p. 4-26. 2013.

FLEURY, M. Busi-Nenge, les hommes-forêt. Essai d'ethnobotanique chez les Aluku (Boni) en Guyane française. 1991. (PhD). Université Paris VI, Paris, 1991.

GRENAND, P. et al. Pharmacopées traditionnelles en Guyane: Créoles, Wayãpi, Palikur. Paris: IRD Editions. 2004. 
GUIMARÃES, L. R. C. et al. Activity of the julocrotine, a glutarimide alkaloid from Croton pullei var. glabrior, on Leishmania (L.) amazonensis. Parasitology Research, v. 107, n. 5, p. 1075-1081. 2010. https://doi.org/10.1007/s00436-010-1973-0. Accessed on: Jul. 29, 2021.

HAJDU, Z.; HOHMANN, J. An ethnopharmacological survey of the traditional medicine utilized in the community of Porvenir, Bajo Paraguá Indian Reservation, Bolivia. Journal of Ethnopharmacology, Pretoria, v. 139, n. 3, p. 838-857. 2012. https://doi.org/10.1016/j.jep.2011.12.029. Accessed on: Jul. 29, 2021.

HAWKINS, J.; TEIXIDOR TONEU, I. Defining 'ethnobotanical convergence'. Trends in plant science, v. 22, n. 8, p. 639-640. 2017. https://doi.org/10.1016/j.tplants.2017.06.002. Accessed on: Jul. 29, 2021.

HERNDON, C. N. et al. Disease concepts and treatment by tribal healers of an Amazonian forest culture. Journal of Ethnobiology and Ethnomedicine, Nashville, v. 5, n. 1, p. 1-22. 2009. https://doi.org/10.1186/1746-4269-5-27. Accessed on: Jul. 29, 2021.

HITZIGER, M. et al. Maya phytomedicine in Guatemala-Can cooperative research change ethnopharmacological paradigms? Journal of Ethnopharmacology, Pretoria, v. 186, p. 61-72. 2016. https://doi.org/10.1016/j.jep.2016.03.040. Accessed on: Jul. 29, 2021.

HOUGHTON, P. J.; OSIBOGUN, I. M. Flowering plants used against snakebite. Journal of Ethnopharmacology, Pretoria, v. 39, n. 1, p. 1-29. 1993. https://doi.org/10.1016/03788741(93)90047-9. Accessed on: Jul. 29, 2021.

INSTITUTO SOCIOAMBIENTAL. Povos indígenas do Brazil: Demografia. São Paulo, 2018.

JOHNSTON, M.; COLQUHOUN, A. Preliminary ethnobotanical survey of Kurupukari: an Amerindian settlement of Central Guyana. Economic Botany, New York, v. 50, n. 2, p. 182-194. 1996. https://doi.org/10.1007/BF02861450. Accessed on: Jul. 29, 2021.

KFFURI, C. W. et al. Antimalarial plants used by indigenous people of the Upper Rio Negro in Amazonas, Brazil. Journal of Ethnopharmacology, v. 178, p. 188-198. 2016.

KIM, D. et al. Dental otalgia. The Journal of Laryngology \& Otology, v. 121, n. 12, p. 11291134. 2007. https://doi.org/10.1017/S0022215107000333. Accessed on: Jul. 29, 2021.

LACHMAN-WHITE, D. A.; ADAMS, C. D.; TROTZ, U. D. A guide to the medicinal plants of coastal Guyana. London: Commonwealth Science Council. 1987.

LEITE, M. D. G. R. et al. Estudo farmacológico comparativo de Mikania glomerata Sprengel (guaco), Justicia pectoralis Jacq (anador) e Torresea cearensis (cumaru). Rev. Bras. Farm, Rio de Janeiro, v. 74, p. 12-15. 1993.

LEWIS, W.; ELVIN-LEWIS, M.; GNERRE, M. Introduction to the ethnobotanical pharmacopeia of the Amazonian Jivaro of Peru. Wageningen: Pudoc. 1987.

LI, X.-C. et al. A new naphthopyrone derivative from Cassia quinquangulata and structural revision of quinquangulin and its glycosides. Journal of natural products, Washington, v. 64, n. 9, p. 1153-1156. 2001. https://doi.org/10.1021/np010173h. Accessed on: Jul. 29, 2021.

LOUZADA, J. et al. The impact of imported malaria by gold miners in Roraima: characterizing the spatial dynamics of autochthonous and imported malaria in an urban region of Boa Vista. Memórias do Instituto Oswaldo Cruz, Rio de Janeiro, v. 115, p. 1-10. 2020. https://doi.org/10.1590/0074-02760200043. Accessed on: Jul. 29, 2021. 
LUZ, F. J. F. Plantas medicinais de uso popular em Boa Vista, Roraima, Brasil. Horticultura Brasileira, Recife, v. 19, n. 1, p. 88-96. 2001. https://doi.org/10.1590/S010205362001000100019. Accessed on: Jul. 29, 2021.

MILLIKEN, W. Algumas plantas usadas no tratamento de malária no estado de Roraima. London: Royal Botanic Gardens, Kew. 1995a. 67p

MILLIKEN, W. Malaria, medicinal plants and the Yanomami Indians. Rainforest Medical Bulletin, v. 2, n. 1, p. 3. 1995b.

MILLIKEN, W. Traditional anti-malarial medicine in Roraima, Brazil. Economic Botany, New York, v. 51, n. 3, p. 212-237. 1997. https://doi.org/10.1007/BF02862091. Accessed on: Jul. 29, 2021.

MILLIKEN, W. Unpublished anti-malarial plants from Roraima, Brazil. London: Royal Botanic Gardens, Kew n.d.

MILLIKEN, W.; ALBERT, B. The use of medicinal plants by the Yanomami Indians of Brazil. Economic Botany, New York, v. 50, n. 1, p. 10-25. 1996. https://doi.org/10.1007/BF02862108. Accessed on: Jul. 29, 2021.

MILLIKEN, W. The use of medicinal plants by the Yanomami Indians of Brazil, Part II. Economic Botany, New York, v. 51, n. 3, p. 264-278. 1997. https://doi.org/10.1007/BF02862096. Accessed on: Jul. 29, 2021.

MILLIKEN, W. et al. The ethnobotany of the Waimiri Atroari Indians of Brazil. London: Royal Botanic Gardens, Kew. 1992.

MILLIKEN, W. et al. Plants used traditionally as antimalarials in Latin America: mining the Tree of Life for potential new medicines. Journal of Ethnopharmacology, Pretoria, V. 279, p. 114221. 2021. https://doi.org/10.1016/j.jep.2021.114221. Accessed on: Jul. 29, 2021.

MONTEIRO, M. V. B. et al. Ethnoveterinary knowledge of the inhabitants of Marajó Island, Eastern Amazonia, Brazil. Acta Amazonica, Manaus, v. 41, n. 2, p. 233-242. 2011. https://doi.org/10.1590/S0044-59672011000200007. Accessed on: Jul. 29, 2021.

MORS, W. B.; RIZZINI, C. T.; PEREIRA, N. A. Medicinal plants of Brazil. Michigan: Reference Publications, Algonac. 2000.

MUÑOZ, V. et al. A search for natural bioactive compounds in Bolivia through a multidisciplinary approach: Part I. Evaluation of the antimalarial activity of plants used by the Chacobo Indians. Journal of Ethnopharmacology, Pretoria, v. 69, n. 2, p. 127-137. 2000. https://doi.org/10.1016/S0378-8741(01)00270-7. Accessed on: Jul. 29, 2021.

NGUYEN, T.-T. et al. In vitro antimycobacterial studies of flavonols from Bauhinia vahlii Wight and Arn. 3 Biotech, v. 11, n. 3, p. 1-5. 2021. https://doi.org/10.1007/s13205-02102672-4. Accessed on: Jul. 29, 2021.

ODONNE, G. et al. When local phytotherapies meet biomedicine. Cross-sectional study of knowledge and intercultural practices against malaria in Eastern French Guiana. Journal of Ethnopharmacology, Pretoria, v. 279, p. 114384. 2021. https://doi.org/10.1016/j.jep.2021.114384. Accessed on: Jul. 29, 2021.

ODONNE, G. et al. Medical ethnobotany of the Chayahuita of the Paranapura basin (Peruvian Amazon). Journal of Ethnopharmacology, Pretoria, v. 146, n. 1, p. 127-153. 2013. https://doi.org/10.1016/j.jep.2012.12.014. Accessed on: Jul. 29, 2021. 
OLIVEIRA, D. R. et al. Ethnopharmacological evaluation of medicinal plants used against malaria by quilombola communities from Oriximiná, Brazil. Journal of Ethnopharmacology, Pretoria, v. 173, p. 424-434. 2015. https://doi.org/10.1016/j.jep.2015.07.035. Accessed on: Jul. 29, 2021.

OLIVEIRA, D. R. et al. Ethnopharmacological versus random plant selection methods for the evaluation of the antimycobacterial activity. Revista Brasileira de Farmacognosia, Curitiba, v. 21, n. 5, p. 793-806. 2011. https://doi.org/10.1590/S0102695X2011005000084. Accessed on: Jul. 29, 2021.

OLIVEIRA, D. R. et al. Ethnopharmacological studies of Lippia origanoides. Revista Brasileira de Farmacognosia, Curitiba, v. 24, n. 2, p. 206-214. 2014. https://doi.org/10.1016/j.bjp.2014.03.001. Accessed on: Jul. 29, 2021.

PANIAGUA-ZAMBRANA, N. Y. et al. Who should conduct ethnobotanical studies? Effects of different interviewers in the case of the Chácobo Ethnobotany project, Beni, Bolivia. Journal of Ethnobiology and Ethnomedicine, Nashville, v. 14, n. 1, p. 1-14. 2018. https://doi.org/10.1186/s13002-018-0210-2. Accessed on: Jul. 29, 2021.

PEDROLLO, C. T. et al. Medicinal plants at Rio Jauaperi, Brazilian Amazon: Ethnobotanical survey and environmental conservation. Journal of $\begin{array}{llllll}\text { Ethnopharmacology, Pretoria, } & \text { v. 1816, }\end{array}$ https://doi.org/10.1016/j.jep.2016.03.055. Accessed on: Jul. 29, 2021.

PELLEGRINI, M. A. O lugar dos Yanomami doentes no sistema único de saúde. In: RICARDO, C. A. (Ed.). Povos Indígenas no Brazil. São Paulo: Instituto Socioambiental, 1996.

PINHEIRO, R. P. et al. Identification of compounds from Palicourea rigida leaves with topical anti-inflammatory potential using experimental models. Inflammopharmacology, v. 26, n. 4, p. 1005-1016. 2018. https://doi.org/10.1007/s10787-0170415-3. Accessed on: Jul. 29, 2021.

PRANCE, G. T. An ethnobotanical comparison of four tribes of Amazonian Indians. Acta Amazonica, Manaus, v. 2, n. 2, p. 7-27. 1972. https://doi.org/10.1590/1809-43921972022007. Accessed on: Jul. 29, 2021.

RAMALHO, M. et al. Fitoterapia: una estratégia terapêutica natural do Amapá. In: BUCHILLET, D. (Ed.). Medicinas tradicionais e medicina Ocidental na Amazónia. Belém: Ediciones CEJUP, 1991. p.413-453.

RAMIREZ, C. R. Ethnobotany and the loss of traditional knowledge in the 21st century. Ethnobotany Research and Applications, v. 5, p. 245-247. 2007. https://doi.org/10.17348/era.5.0.245-247. Accessed on: Jul.29, 2021.

RAMÍREZ, O.; BLAIR, S. Ethnobotany of medicinal plants used to treat malaria by traditional healers from ten indigenous Colombian communities located in Vaupes Medio. Biodiversity International Journal, v. 1, n. 4, p. 00022. 2017. https://doi.org/10.15406/bij.2017.01.00022. Accessed on: Jul. 29, 2021

REYES-GARCÍA, V. et al. Evidence of traditional knowledge loss among a contemporary indigenous society. Evolution and Human Behavior, v. 34, n. 4, p. 249-257. 2013. https://doi.org/10.1016/j.evolhumbehav.2013.03.002. Accessed on: Jul. 29, 2021.

RIBEIRO, R. V. et al. Ethnobotanical study of medicinal plants used by Ribeirinhos in the North Araguaia microregion, Mato Grosso, Brazil. Journal of Ethnopharmacology, 
Pretoria, v. 205, p. 69-102. 2017. https://doi.org/10.1016/j.jep.2017.04.023. Accessed on: Jul. $29,2021$.

RITTER, M. R. et al. Bibliometric analysis of ethnobotanical research in Brazil (19882013). Acta Botanica Brasilica, Brasília, v. 29, n. 1, p. 113-119. 2015. https://doi.org/10.1590/0102-33062014abb3524. Accessed on: Jul.29, 2021.

RODRIGUES, E. et al. Participatory ethnobotany and conservation: a methodological case study conducted with quilombola communities in Brazil's Atlantic Forest. Journal of Ethnobiology and Ethnomedicine, Nashville, v. 16, n. 1, p. 1-12. 2020. https://doi.org/10.1186/s13002-019-0352-x. Accessed on: Jul. 29, 2021.

ROVIRA, I. et al. Antimicrobial activity of Neotropical wood and bark extracts. $\begin{array}{lllllll}\text { Pharmaceutical Biology, } & \text { v. 37, n. } 3, \quad \text { p. } & \text { 208-215. } & 1999 .\end{array}$ https://doi.org/10.1076/phbi.37.3.208.6297. Accessed on: Jul. 29, 2021.

SALATINO, A.; SALATINO, M. L. F.; NEGRI, G. Traditional uses, chemistry and pharmacology of Croton species (Euphorbiaceae). Journal of the Brazilian Chemical Society, v. 18, n. 1, p. 11-33. 2007. https://doi.org/10.1590/s0103-50532007000100002. Accessed on: Jul. 29, 2021.

SALTOS, R. V. A. et al. The use of medicinal plants by rural populations of the Pastaza province in the Ecuadorian Amazon. Acta Amazonica, Manaus, v. 46, n. 4, p. 355-366. 2016. https://doi.org/10.1590/1809-4392201600305. Accessed on: Jul. 29, 2021.

SANZ-BISET, J.; CANIGUERAL, S. Plant use in the medicinal practices known as "strict diets" in Chazuta valley (Peruvian Amazon). Journal of Ethnopharmacology, Pretoria, v. 137, n. 1, p. 271-288. 2011. https://doi.org/10.1016/j.jep.2011.05.021. Accessed on: Jul. 29, 2021.

SASLIS-LAGOUDAKIS, C. H. et al. Cross-cultural comparison of three medicinal floras and implications for bioprospecting strategies. Journal of Ethnopharmacology, Pretoria, v. 135, n. 2, p. 476-487. 2011. https://doi.org/10.1016/j.jep.2011.03.044. Accessed on: Jul. 29, 2021.

SCALIA, R. A. et al. In vitro antimicrobial activity of Luffa operculata. Brazilian Journal $\begin{array}{llllllll}\text { of Otorhinolaryngology, } & \text { v. } & 81, & \text { n. } & 4, & \text { p. } & 422-430 .\end{array}$ https://doi.org/10.1016/j.bjorl.2014.07.015. Accessed on: Jul. 29, 2021.

SCHULTES, R. E. De Plantis Toxicariis e Mundo Novo Tropicale commentationes xxxi: further ethnopharmacological notes on malpighiaceous plants of the Northwestern Amazon. Botanical Museum Leaflets, Harvard University, v. 29, n. 2, p. 133-137. 1983. https://www.jstor.org/stable/41762845. Accessed on: Jul. 29, 2021.

SCHULTES, R. E.; RAFFAUF, R. F. The healing forest: medicinal and toxic plants of the Northwest Amazonia. Portland: Dioscorides Press. 1990.

SHANLEY, P.; LUZ, L. The impacts of forest degradation on medicinal plant use and implications for health care in eastern Amazonia. BioScience, Oxford, v. 53, n. 6, p. 573584. 2003. https://doi.org/10.1641/0006-3568(2003)053[0573:tiofdo]2.0.co;2. Accessed on: Jul. 29, 2021.

SILVA, L. et al. Preclinical evaluation of Luffa operculata Cogn. and its main active principle in the treatment of bacterial rhinosinusitis. Brazilian Journal of Otorhinolaryngology, v. 84, n. 1, p. 82-88. 2018. https://doi.org/10.1016/j.bjorl.2016.11.004. Accessed on: Jul. 29, 2021. 
SILVA, M. D.; OLIVEIRA, D. R. D. The new Brazilian legislation on access to the biodiversity (Law 13,123/15 and Decree 8772/16). Brazilian Journal of Microbiology, São Paulo, v. 49, n. 1, p. 1-4. 2018. https://doi.org/10.1016/j.bjm.2017.12.001. Accessed on: Jul. 29, 2021.

STOREY, C.; SALEM, J. I. Lay use of Amazonian plants for the treatment of tuberculosis. Acta Amazonica, Manaus, v. 27, n. 3, p. 175-182. 1997. https://doi.org/10.1590/180943921997273182. Accessed on: Jul. 29, 2021.

VAN ANDEL, T. et al. The medicinal plant trade in Suriname. Ethnobotany Research and Applications, v. 5, p. 351-372. 2007. https://doi.org/10.17348/era.5.0.351-372. Accessed on: Jul. 29, 2021.

VAN ANDEL, T. R. Non-timber forest products of the North-West District of Guyana. Utrecht: Utrecht University. 2000.

VAN DEN BERG, M. E.; SILVA, M. H. L. D. Contribuição ao conhecimento da flora medicinal de Roraima. Acta amazônica, Manaus, v. 18, n. 1-2, p. 23-35. 1988. https://doi.org/10.1590/1809-43921988185035. Accessed on: Jul. 29, 2021.

VANDEBROEK, I. Intercultural health and ethnobotany: How to improve healthcare for underserved and minority communities? Journal of Ethnopharmacology, Pretoria, v. 148, n. 3, p. 746-754. 2013. https://doi.org/10.1016/j.jep.2013.05.039. Accessed on: Jul. 29, 2021.

VANDEBROEK, I. et al. Use of medicinal plants and pharmaceuticals by indigenous communities in the Bolivian Andes and Amazon. Bulletin of the World Health Organization, Geneva, v. 82, p. 243-250. 2004.

VERA-KU, M. et al. Medicinal potions used against infectious bowel diseases in Mayan traditional medicine. Journal of Ethnopharmacology, Pretoria, v. 132, n. 1, p. 303-308. 2010. https://doi.org/10.1016/j.jep.2010.08.040. Accessed on: Jul. 29, 2021.

WECKMÜLLER, H. et al. Changes in medicinal plant knowledge among the Waorani Society, Ecuador. Sustainability, v. 11, n. 16, p. 4460. 2019. https://doi.org/10.3390/su11164460. Accessed on: Jul. 29, 2021.

YANOMAMI, M. et al. Manual dos remédios tradicionais Yanomami. Boa Vista: Hutukara Associação Yanomami. 2015.

ZAMBRANA, N. Y. P. et al. Traditional knowledge hiding in plain sight - twenty-first century ethnobotany of the Chácobo in Beni, Bolivia. Journal of Ethnobiology and Ethnomedicine, Nashville, v. 13, n. 1, p. 57. 2017. https://doi.org/10.1186/s13002-017-0179-2. Accessed on: Jul. 29, 2021.

ZENT, S. Processual perspectives on traditional environmental knowledge. Understanding cultural transmission in anthropology, p. 213-65. 2013.

Recebido em: 10/05/2021 Aprovado em: 13/08/2021 Publicado em: 21/09/2021 
Appendix 1. Medicinal plants in Roraima, Brazil. In the 'Common name(s)' column, a name in parentheses indicates its common use in Portuguese rather than indigenous names. The superscript numbers after the use (informant name and locality) are: ${ }^{1}$ Raimundo, Sorocaima II; ${ }^{2}$ Bento, Bananal; ${ }^{3}$ Arlindo, Manalai; ${ }^{4}$ Joachim, Raposa; ${ }^{5}$ João, Raposa; ${ }^{6}$ Totoari, Jatapuzinho; ${ }^{7}$ Ines, Maturuca; ${ }^{8}$ MSF meeting, Mangueira; ${ }^{9}$ Virginia, Raposa; ${ }^{10}$ Oreco, Araça; ${ }^{11}$ Ilvaldo/Dulcimar/Martins, Maturuca; ${ }^{12}$ Indet., Araça; ${ }^{13}$ Martins, Manalai; ${ }^{14}$ Alvino, Malacacheta; ${ }^{15}$ Maria Lucia, Maturuca; ${ }^{16}$ Narcisa, Clarenço, Serra do Sol; ${ }^{17}$ Teresa, Boca da Mata; ${ }^{18}$ João Sales, Manalai.

\begin{tabular}{lllll}
\hline Family & Species & Common name(s) & People & Voucher \\
\hline Acanthaceae & Dianthera pectoralis (Jacq.) J.F.Gmel. & (anador) & Macuxi & WM 2281 \\
\hline
\end{tabular}

Use: Headache and body pains - analgesic. Infusion of 3 leaves is drunk. ${ }^{1}$

Corresponding: Infusion for headache caused by blows to the head (DEFILIPPS et al., 2004). Used to treat headache in Roraima (ARAÚJO, 2018) and body pains (DE SOUZA AND PASA, 2013). Analgesic (LEITE et al., 1993).

\begin{tabular}{|c|c|c|c|c|}
\hline Annonaceae & Anaxagorea dolichocarpa Sprague \& Sandw. & kirabipi yekë & Taurepang & WM 2274 \\
\hline
\end{tabular}
should be followed by drinking clear water. ${ }^{2}$

Corresponding: A. acuminata (Dunal) A.DC used by the Yanomami to treat fevers (MILLIKEN, n.d.).

\begin{tabular}{|c|c|c|c|c|}
\hline Annonaceae & Duguetia cf. neglecta Sandw. & Arelyaekë & Ingarikó & WM 2226 \\
\hline
\end{tabular}

Corresponding: Used as a cough remedy among the Kurupukari, Guyana (JOHNSTON AND COLQUHOUN, 1996).

\begin{tabular}{|c|c|c|c|}
\hline Apocynaceae & Aspidosperma excelsum Benth. & Ingarikó & WM 2228 \\
\hline
\end{tabular}

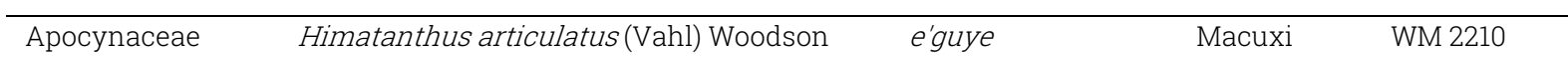
Use: Remedy for kidney stones. One seed is taken daily, crushed in a glass of water. ${ }^{4}$ Remedy for spleen disorders
and vermifuge. A decoction of the inner bark is drunk. ${ }^{5}$

Corresponding: Used to treat kidneys in Roraima (DE OLIVEIRA, 2016). Used as vermifuge (FLEURY, 1991; MORS et al., 2000).

\begin{tabular}{|c|c|c|c|c|}
\hline Araceae & Philodendron solimoesense A.C.Sm. & furuweto & Wai-Wai & WM 1790 \\
\hline \multicolumn{5}{|c|}{$\begin{array}{l}\text { Use: Remedy for ponerine ant stings and snake bite. Scrapings of the aerial roots are applied to the sting/bite. } \\
\text { Corresponding: Exudate from aerial roots for scorpion stings (MILLIKEN AND ALBERT, 1996) and snake bite } \\
\text { (PEDROLLO et al., 2016). Other Philodendron spp. used for ponerine ant stings (SCHULTES AND RAFFAUF, 1990; } \\
\text { MILLIKENet al., 1992; DEFILIPPS et al., 2004) and snake bite (DAVIS AND YOST, 1983). }\end{array}$} \\
\hline Araliaceae & $\begin{array}{l}\text { Didymopanax morototoni (Aubl.) Decne \& } \\
\text { Planch. }\end{array}$ & $\begin{array}{l}\text { ponayekie } \\
\text { kala'kilu }^{6}\end{array}$ & $\begin{array}{l}\text { Ingarikó, } \\
\text { Wai-Wai }\end{array}$ & $\begin{array}{l}\text { WM 2230, } \\
2243\end{array}$ \\
\hline
\end{tabular}

\footnotetext{
Use: Cough remedy. A decoction of the bark is used as an external bath. ${ }^{3}$ Remedy for stomach-ache. Scrapings of the inner bark are boiled in water and the extract is drunk. ${ }^{6}$
}

Corresponding: Treat colds in Suriname (VAN ANDEL et al., 2007) and respiratory affections (ARAMBARRI et al., 2008).

\begin{tabular}{llc}
\hline Asteraceae & Bidens bipinnata L. & WMadã (picão) 2215 \\
\hline $\begin{array}{l}\text { Use: Remedy for liver disorders. A decoction of the roots (2 or } 3 \text { plants in } 1 \text { litre of water) is drunk (1 spoon 3x } \\
\text { daily) until cured. }\end{array}$
\end{tabular}

Corresponding: Used to treat liver problems in Brazil (DI STASI et al., 1994; OLIVEIRA et al., 2015). Bidens pilosa L. is used in Roraima to treat hepatitis (ARAÚJO, 2018), and elsewhere in Brazil (ANTUNES MACIEL AND GUARIM NETO, 2006; BITENCOURT et al., 2014; RIBEIRO et al., 2017). 


\begin{tabular}{lll}
\hline Caricaceae & Carica papaya L. & Taurepang
\end{tabular}

Use: Vomiting and dysentery. An infusion of the roots is drunk. ${ }^{2}$

Corresponding: Treat diarrhoea in NW Guyana (DEFILIPPS et al., 2004) and vomiting in Roraima (DE OLIVEIRA, 2016).

\begin{tabular}{lcc}
\hline Cucurbitaceae Luffa operculata (L.) Cogn. & (cabaçinha) & Macuxi \\
\hline Use: Remedy for sinusitis. A decoction of the fruit is poured into the nose when the patient is lying down. It \\
loosens the obstructions in the sinuses. \\
Corresponding: Sold as cure for sinusitis in Boa Vista (LUZ, 2001). Commonly used for the same purpose in Latin \\
America (CÁCERES, 1996; SILVA et al., 2018), and shows antimicrobial activity against Streptococcus and \\
Staphylococcus species (SCALIA et al., 2015). \\
Curatella americana L. & (caimbé) & Wapixana, \\
\hline Dilleniaceae & & Macuxi
\end{tabular}

Use: Diabetes remedy. Decoction of bark is drunk. ${ }^{8}$ Remedy for cuts and wounds. Scrapings of the inner bark are rubbed on the wound. ${ }^{5}$

Corresponding: Diabetes in Mato Grosso (DE OLIVEIRA et al., 2015). Infusion of leaves as an astringent in French Guiana (DEFILIPPS et al., 2004); for healing (DOYLE, 1985).

\begin{tabular}{|c|c|c|c|c|}
\hline Euphorbiaceae & Croton cf. parodianus Croizat & ipoye (velame) & Macuxi & WM 2267 \\
\hline \multicolumn{5}{|c|}{ Use: Dysentery remedy. A tea made from the old yellow leaves is drunk. ${ }^{9}$} \\
\hline \multicolumn{5}{|c|}{$\begin{array}{l}\text { Corresponding: Several Croton spp. are used to treat dysentery in South America, Africa and Asia (SALATINO et } \\
\text { al., 2007). }\end{array}$} \\
\hline Euphorbiaceae & Croton pullei Lanj. & xixinatë & Wai-Wai & WM 2244 \\
\hline
\end{tabular}

Use: Remedy for cutaneous leishmaniasis. Scrapings of the inner bark are applied to the lesions. ${ }^{6}$

Corresponding: Bark/leaves are placed in fire and rubbed on leg sores by the Tiriyo in Suriname (DEFILIPPS et al., 2004). Reduce protomastigote growth in Leishmania amazonensis (GUIMARÃES et al., 2010).

\begin{tabular}{|c|c|c|c|c|}
\hline Euphorbiaceae & Hevea guianensis Aubl. & Oyosi & Wai-Wai & WM 2255 \\
\hline
\end{tabular}
Use: Remedy for botfly infestation of the skin. The latex is applied to the skin above the larva and left there until it dies and comes out. ${ }^{6}$

Corresponding: Latex is applied to kill parasitic botfly larvae by the Tiriyo in Suriname (DEFILIPPS et al., 2004), the Waimiri Atroari (MILLIKENet al., 1992) and the Waorani in Ecuador (DAVIS AND YOST, 1983).

\begin{tabular}{lcc}
\hline Euphorbiaceae Sagotia racemosa Baill. & tunalalu Wai-Wai & WM 2263 \\
\hline $\begin{array}{l}\text { Use: Toothache remedy. The yellow liquid exuded from the petiole is put into the cavity; excessive use causes the } \\
\text { tooth to crumble. }\end{array}$
\end{tabular}

Corresponding: Use to treat ear ache by the Jívaro in Peru (LEWIS et al., 1987).

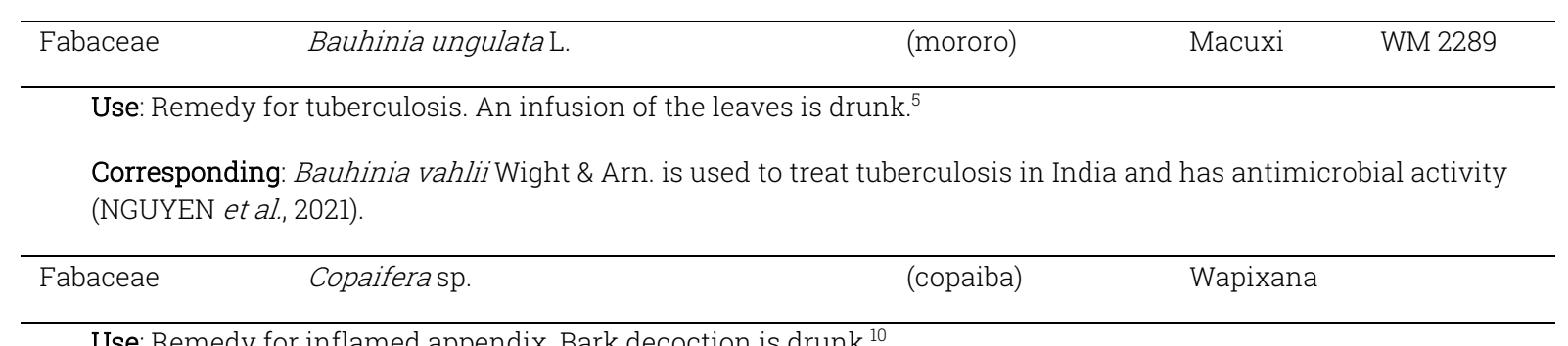

Use: Remedy for inflamed appendix. Bark decoction is drunk. ${ }^{10}$

Corresponding: Used to treat internal inflammations in Roraima (DE OLIVEIRA 2016; DE OLIVEIRA, ALMEIDA, et al., 2017). 


\begin{tabular}{|c|c|c|c|}
\hline Fabaceae & Dinizia excelsa Ducke & Wai-Wai & WM 2258 \\
\hline
\end{tabular}

\begin{tabular}{|c|c|c|c|}
\hline Fabaceae & Hymenaea courbaril L. & (jatobá) & Wapishana \\
\hline \multicolumn{4}{|c|}{ Use: Remedy for wounds that will not heal, and for coughs \& colds. ${ }^{10}$} \\
\hline \multicolumn{4}{|c|}{$\begin{array}{l}\text { Corresponding: Resin used to treat fresh wounds, and bark treat coughs and colds in NW Guyana (DE FILIPPS et } \\
\text { al., 2004). Also for coughs, colds and influenza in Brazil (DE ALBUQUERQUE et al., 2007; HAJDU AND HOHMANN, } \\
\text { 2012), and wound healing (BIESKI et al., 2015). }\end{array}$} \\
\hline Fabaceae & $\begin{array}{l}\text { Leptolobium stirtonii (Aymard \& } \\
\text { V.González) Sch.Rodr. \& A.M.G.Azevedo }\end{array}$ & walaweri(darura) & WM 2216 \\
\hline
\end{tabular}

Use: Remedy for headache, and preventative for tooth decay. A decoction of the bark (approx. $5 \mathrm{~cm} x 5 \mathrm{~cm}$ in 1 litre of water), is drunk (1 spoon $3 x$ daily). The bark is chewed to prevent tooth decay. ${ }^{11}$

Corresponding: Leptolobium nitens Vogel (darora) is used to treat headaches in Roraima and weak teeth (DE OLIVEIRA, 2016).

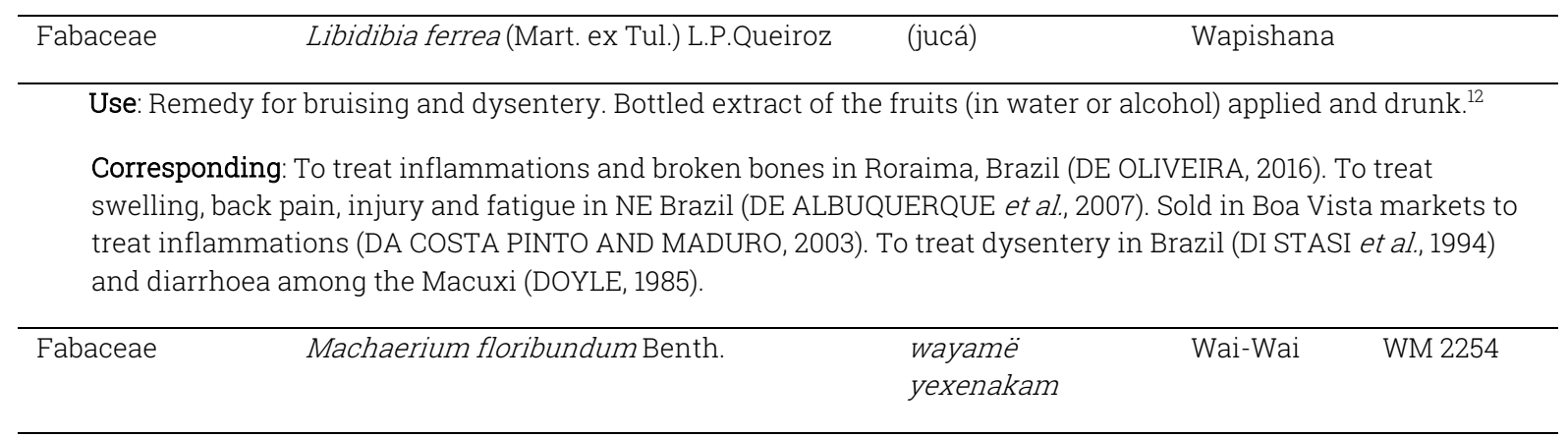

Use: Stomach-ache and diarrhoea remedy. An infusion of the inner bark is drunk. ${ }^{6}$

Corresponding: Used for diarrhoea and haemorrhage in NW Guyana (DEFILIPPS et al., 2004), and gastro-intestinal ulcers in Peru (ODONNE et al., 2013).

\begin{tabular}{ccc}
\hline Fabaceae & Macrolobium bifolium (Aubl.) Pers. & Ingarikó \\
\hline Use: Diarrhoea/stomach-ache remedy. A decoction of the inner bark is drunk. & W235 \\
Corresponding: Macrolobium acaciifolium (Benth.) Benth is used to treat diarrhoea (DUKE AND VASQUEZ, 1994).
\end{tabular}

\begin{tabular}{lll}
\hline Fabaceae Schnella guianensis(Aubl.) Wunderlin & $\begin{array}{l}\text { wayami kayinfwo } \\
\text { kapoyenkëma } \\
\text { poyeke } \dot{e}^{3}\end{array}$ & Wai-Wai, \\
& Ingarikó
\end{tabular}

\footnotetext{
Use: Diarrhoea remedy. An infusion of the stem is drunk. ${ }^{6}$ Diarrhoea/stomach-ache remedy. The stem is crushed and mixed in hot or cold water, and the extract is drunk. ${ }^{3}$
}

Corresponding: Sap is used to treat diarrhoea in NW Guyana, and bark decoction drunk as an antidiarrhoeal, by the Patamona (DEFILIPPS et al., 2004). Used by the Yanomami, the Chacobo and the Waimiri Atroari for diarrhoea (MILLIKEN et al., 1992; MUNOZ et al., 2000; YANOMAMI et al., 2015).

\begin{tabular}{|c|c|c|c|c|}
\hline Fabaceae & Senna obtusifolia (L.) Irwin \& Barneby & (mata pasto) & Wapishana & WM 2209 \\
\hline \multicolumn{5}{|c|}{ Use: Remedy for skin disorders (red rash). Crushed plant is rubbed on inflamed skin. ${ }^{14}$} \\
\hline \multicolumn{5}{|c|}{$\begin{array}{l}\text { Corresponding: To treat measles in Peru (SANZ-BISET AND CANIGUERAL, 2011), and skin problems in Pará } \\
\text { (MONTEIRO et al., 2011). }\end{array}$} \\
\hline Fabaceae & $\begin{array}{l}\text { Senna quinquangulata (Rich.) H.S.Irwin \& } \\
\text { Barneby }\end{array}$ & kataweriweri & Wai-Wai & WM 2257 \\
\hline
\end{tabular}

Use: Stomach-ache remedy. An infusion of the inner bark is drunk. ${ }^{6}$

Corresponding: This species contains quinquangulin, which is antibacterial (LI et al., 2001). 


\begin{tabular}{|c|c|c|c|c|}
\hline Lauraceae & Licaria guianensis Aubl. & Iyilo & Wai-Wai & WM2246 \\
\hline
\end{tabular}

Use: Stomach-ache remedy. A decoction of the wood is drunk. ${ }^{6}$

Corresponding: Licaria camara (Rob. Schomb.) Kostermans is used to treat bowel cramps, dysentery and diarrhoea in Guyana (DEFILIPPS et al., 2004).

\begin{tabular}{|c|c|c|c|c|}
\hline Lecythidaceae & Cariniana micrantha Ducke & tu'ru & Wai-Wai & WM 2259 \\
\hline
\end{tabular}

Use: Remedy for cuts. The fibres of the inner bark are tied as a plaster around the cut, hastening healing. ${ }^{6}$

Corresponding: Cariniana spp. is used as an antiseptic (ALVES et al., 2008) and general infection in Brazil (RIBEIRO et al., 2017). Sold in the market in Boa Vista to treat inflammations (DA COSTA PINTO AND MADURO, 2003).

\begin{tabular}{|c|c|c|c|c|}
\hline Lecythidaceae & Lecythis cf. lurida(Miers) Mori & makwauru & Wai-Wai & WM 2251 \\
\hline \multicolumn{4}{|c|}{ Use: Remedy for chickenpox. Scrapings of the inner bark are rubbed on the skin. ${ }^{6}$} & \\
\hline Malpighiaceae & Byrsonima crassifolia(L.) Kunth & $\begin{array}{l}\text { muriboyek } \dot{e}^{3} \\
\text { (mirixi) }^{13}\end{array}$ & $\begin{array}{l}\text { Ingarikó, } \\
\text { Macuxi }\end{array}$ & $\begin{array}{l}\text { WM 2234, } \\
2223\end{array}$ \\
\hline
\end{tabular}

Use: Remedy for diarrhoea and stomach-ache. A decoction of the bark is drunk. ${ }^{3}$ Remedy for worms, and for bleeding umbilicus of new-born babies. The bark is chewed, and the juice is swallowed (worms). ${ }^{13}$

Corresponding: Inner bark decoction used as anti-diarrhoeal by the Patamona in Guyana (DEFILIPPS et al., 2004). To treat gastrointestinal disorders and diarrhoea in Brazil and Nicaragua (DOYLE, 1985; BARRETT, 1994; AGRA et al., 2008; DE OLIVEIRA, 2016). Powder from the underside of leaves applied to the cut end of the umbilical cord to prevent infection by the Patamona in Guyana (DEFILIPPS et al., 2004). B. japurensis A.Juss. is used as a vermifuge in the Northwest Amazon (SCHULTES, 1983).

\begin{tabular}{lccc}
\hline Malvaceae & Ayenia tomentosa L. & parainspi part & Macuxi \\
\hline Use: Remedy for grippe. A decoction of the stems is drunk. ${ }^{15}$ & & Wh 223 \\
\hline Marasmiaceae & Rhizomorpha corynephora Kunze & karifamna & Wai-Wai 2260
\end{tabular}
Use: Remedy for urinary disorders - pain and difficulty urinating. An infusion of the fungus is drunk. ${ }^{6}$
Corresponding: Ingested for urinary conditions; rubbed on the abdomen of children with incontinence (DEFILIPPS et al., 2004).

\begin{tabular}{l}
\hline Carapa guianensis Aubl. karapayekë \\
\hline Use: Remedy for measles, chicken pox and diarrhoea/stomach-ache. The seeds are grated and rubbed on the \\
skin. For diarrhoea and stomach-ache, the oil is extracted from the grated seeds and drunk in small quantities. ${ }^{3,}$ \\
13
\end{tabular}

Corresponding: Grated nut, mixed with palm oil is used for measles or chicken-pox by the Patamona in Guyana, and to treat diarrhoea by the Kurupukati in Guyana (DEFILIPPS et al., 2004).

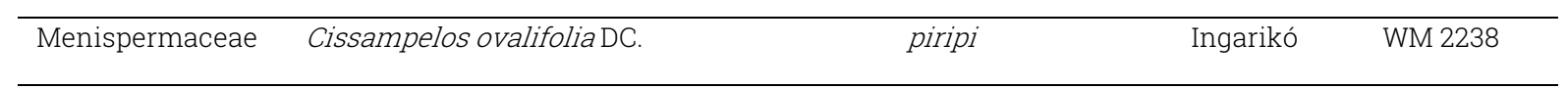

Use: Remedy for diarrhoea and stomach-ache. A decoction of the bitter rhizome is drunk. ${ }^{16}$

Corresponding: Used to treat stomach-ache in Minas Gerais (FERREIRA et al., 2013).

\begin{tabular}{lll}
\hline Moraceae Maquira sclerophylla(Ducke) C.C. Berg yarika Wai-Wai & WM 2249
\end{tabular}

Use: Remedy for wounds/sores and for head lice. The latex is applied to the affected area. For lice, the fruits are crushed into a fine paste and rubbed into the scalp. ${ }^{6}$

Corresponding: M. coriacea (Ducke) C.C.Berg is used as a healing treatment in Peru (ACOSTUPA et al., 2016). 


\begin{tabular}{l} 
Myristicaceae Virola calophylla(Spruce) Warb. \\
\hline $\begin{array}{l}\text { Use: Remedy for oral thrush. A small piece of cotton wool is soaked in the resin from the bark and placed in the } \\
\text { mouth. }\end{array}$ \\
Corresponding: Exudate used in treatment of mouth sores and thrush in NW Guyana (DEFILIPPS et al., 2004).
\end{tabular}

\begin{tabular}{|c|c|c|c|c|}
\hline Myristicaceae & Virola duckei A.C. Smith vel sp. aff. & mayawaru & Wai-Wai & WM 2249 \\
\hline \multicolumn{5}{|c|}{$\begin{array}{l}\text { Use: Remedy for itching sores. Scrapings of the inner bark are rubbed on the affected area, or the resin from the } \\
\text { bark is applied. }\end{array}$} \\
\hline \multicolumn{5}{|c|}{ Corresponding: Resin applied to skin infections by the Quichua in Ecuador (BENNETT AND ALARCÓN, 1994). } \\
\hline Myristicaceae & Virola elongata (Benth.) Warb. & $\begin{array}{l}\text { ayuke } \dot{e}^{2}, \text { kiyakwe } \\
\text { yoso'muru }\end{array}$ & $\begin{array}{l}\text { Taurepang, } \\
\text { Wai-Wai }\end{array}$ & $\begin{array}{l}\text { WM 2273, } \\
2250\end{array}$ \\
\hline
\end{tabular}

Use: Remedy for general body pains (including fever). Cold-water infusion of crushed inner bark drunk (one gourd full). Causes vomiting; should be followed by drinking clear water. ${ }^{2}$ Remedy for oral thrush. A small piece of cotton wool is soaked in the resin from the bark and placed in the mouth. ${ }^{6}$

Corresponding: The Barasana boil leaves and twigs for swollen joints (arthritis) (SCHULTES AND RAFFAUF, 1990). Other Virola species are used to treat fevers (PRANCE, 1972; SCHULTES AND RAFFAUF, 1990). Exudate used for treatment of mouth sores and thrush in NW Guyana (DEFILIPPS et al., 2004).

\begin{tabular}{lllll}
\hline Myrtaceae & $\begin{array}{l}\text { Corymbia citriodora (Hook.) K.D.Hill \& } \\
\text { L.A.S.Johnson }\end{array}$ & (eucalipto) & Macuxi & WM 2282 \\
\hline
\end{tabular}

Use: Cold remedy. An infusion of 5 leaves in 0.5 litres of water is drunk, 1 cup 3x daily. ${ }^{17}$

Corresponding: Used in Mato Grosso to treat colds (BIESKI et al., 2015) and in Amapá (RAMALHO et al., 1991).

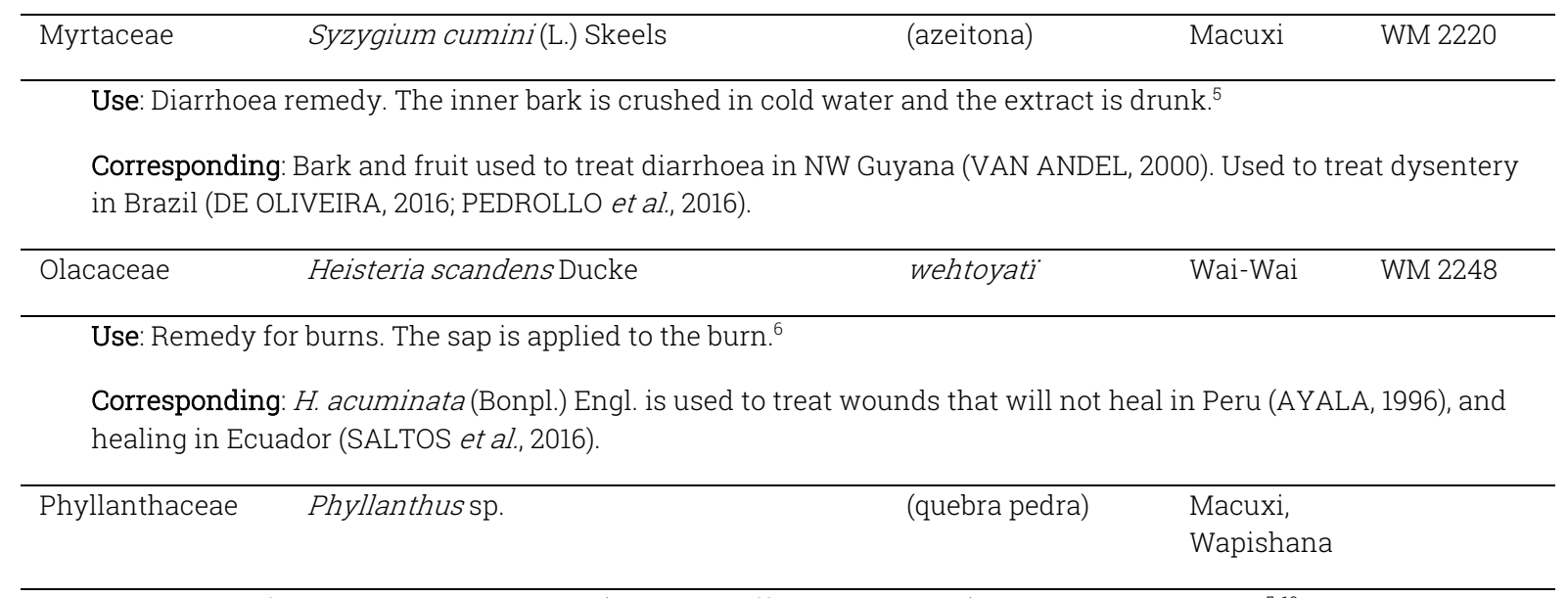

Use: Remedy for urinary tract disorders (pain and difficulty urinating), and kidney problems. ${ }^{5,10}$

Corresponding: Phyllanthus spp. are used to treat kidney infections in Peru (ACOSTUPA et al., 2016), Brazil (DE ALBUQUERQUE et al., 2007; AGRA et al., 2008; BIESKI et al., 2015; DE OLIVEIRA, 2016; ARAÚJO, 2018), and the Guianas (DEFILIPPS et al., 2004).

\begin{tabular}{l} 
Coix lacryma-jobi L. a'najiwaryekë $^{\text {Poaceae }}$ Ingarikó \\
\hline $\begin{array}{l}\text { Use: Snake bite remedy. The seeds are burned, and the ashes are rubbed into the wound; also mixed with cold } \\
\text { water and drunk. }\end{array}$ \\
Corresponding: Used to treat snakebite in India (HOUGHTON AND OSIBOGUN, 1993).
\end{tabular}

\begin{tabular}{lll}
\hline Poaceae & Saccharum officinarum L. & farantxi \\
\hline
\end{tabular}

Use: Snake bite remedy. The juice from the stem is drunk regularly in place of water and is used to bathe the

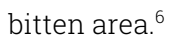

Corresponding: Used to treat snakebite in NW Guyana (VAN ANDEL, 2000). Also used to treat snakebite in SouthEast Asia (HOUGHTON AND OSIBOGUN, 1993). 


\begin{tabular}{|c|c|c|c|c|}
\hline Rhamnaceae & Ampelozizyphus amazonicus Ducke & xiwiriati & Wai-Wai & WM 2264 \\
\hline \multicolumn{5}{|c|}{$\begin{array}{l}\text { Use: Remedy for severe cough (with blood). A hot or cold-water infusion of the inner bark is drunk. 'Burns' the } \\
\text { throat. } 6\end{array}$} \\
\hline \multicolumn{5}{|c|}{$\begin{array}{l}\text { Corresponding: Used to treat tuberculosis in Amazonia (STOREY AND SALEM, 1997). Used to treat colds or flu } \\
\text { ('resfriados') [Specimen C.A. Cid 4107]. }\end{array}$} \\
\hline Rubiaceae & Capirona decorticans Spruce & yasufitxo & Wai-Wai & WM 2262 \\
\hline \multicolumn{5}{|c|}{$\begin{array}{l}\text { Use: Remedy for wounds and sores. A decoction of scrapings of the inner bark is applied to the affected area. } \\
\text { Corresponding: Bark in a maceration to treat furuncles and cutaneous eruptions by the Wayapi in French Guiana } \\
\text { (DEFILIPPS et al., 2004). Used by the Chácobo in Bolivia to treat wounds, cuts, skin, and subcutaneous tissue } \\
\text { (ZAMBRANA et al., 2017). }\end{array}$} \\
\hline Rubiaceae & Genipa americana L. & $\begin{array}{l}\text { (genipapo) } \\
\text { mapada }^{5}\end{array}$ & $\begin{array}{l}\text { Macuxi, } \\
\text { Taurepang }\end{array}$ & WM 2276 \\
\hline
\end{tabular}

Use: Asthma remedy. Pulp from the fruits is removed, and the remaining part boiled down into a syrup and drunk. ${ }^{5}$ Stomach-ache remedy. An infusion of the bark is drunk. ${ }^{2}$

Corresponding: Used to treat asthma and as a purgative in Peru (ACOSTUPA et al., 2016). The bark is used to treat diarrhoea (MORS et al., 2000)

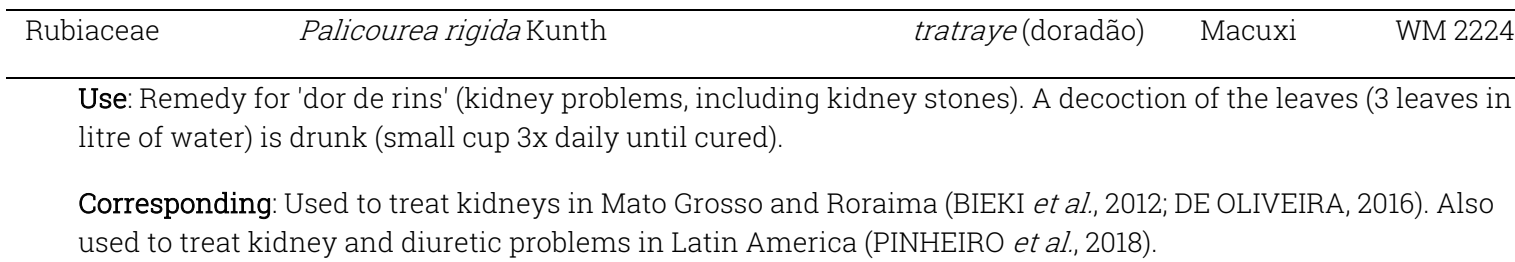

\begin{tabular}{llll}
\hline Siparunaceae & Siparuna guianensis Aubl. & wataku'rang & Taurepang
\end{tabular}

Use: Remedy for fevers. The leaves are boiled in water and used as a steam bath, or alternatively poured over the head and body. ${ }^{2}$

Corresponding: Decoction as a refresher and febrifuge in the Guianas (LACHMAN-WHITE et al., 1987; DEFILIPPS et al., 2004; GRENAND et al., 2004). Also for fevers in Brazil (CAVALCANTE AND FRIKEL, 1973).

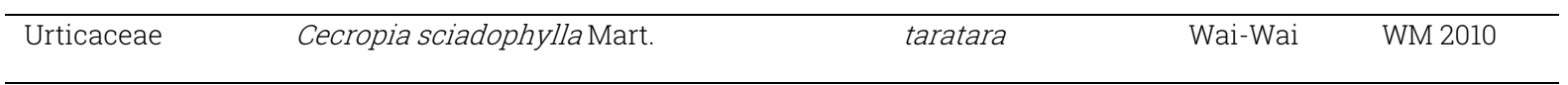

\footnotetext{
Use: Remedy for eye infections. The watery fluid from the cut roots is dripped into the eyes. ${ }^{6}$

Corresponding: The Tiriyo in Suriname apply sap from crushed leaves to treat eye problems (DEFILIPPS et al.,
} 2004).

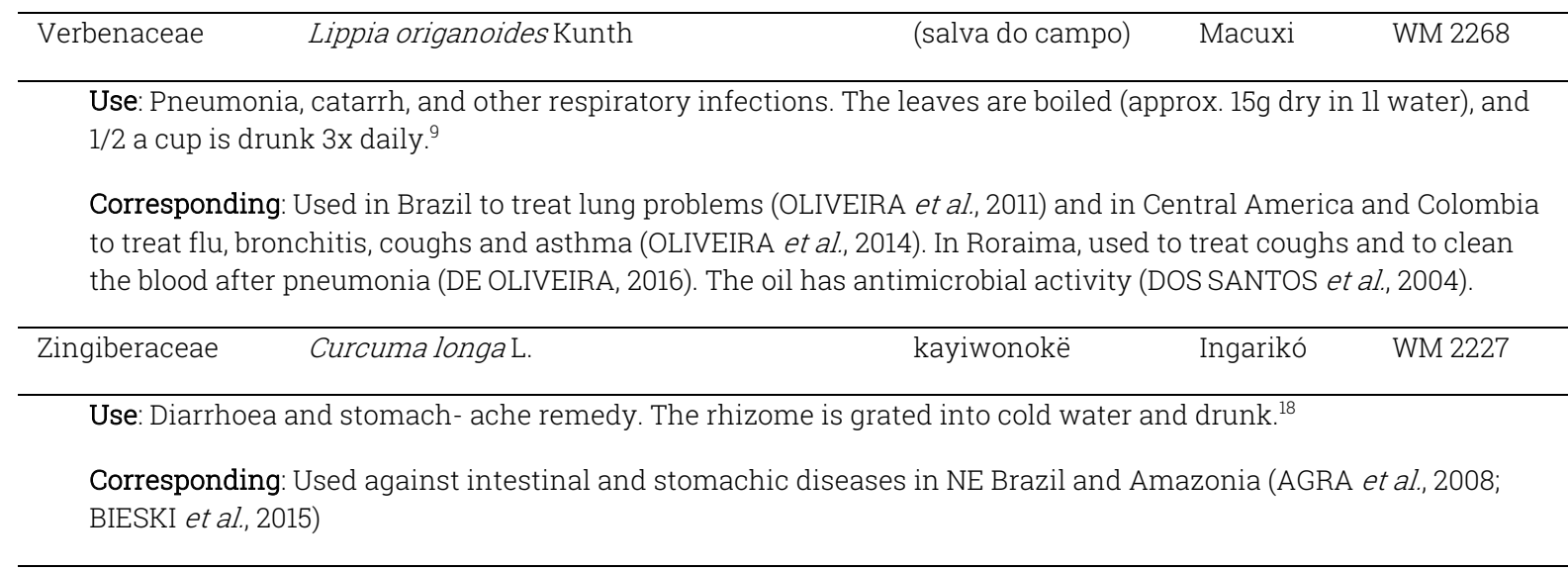

